\title{
A Kelvin-féle görbület kontra a Gibbs-féle felület: a nano-termodinamika két paradigmája
}

\author{
KAPTAY György* \\ Miskolci Egyetem, Nanotechnológiai Tanszék, 3515 Miskolc, Egyetemváros; \\ MTA-ME Anyagtudományi Kutatócsoport, 3515Miskolc, Egyetemváros; \\ Bay Zoltán Alkalmazott Kutatási kft, BAY-ENG, 3519 Miskolc, Iglói út 2.
}

\section{Bevezetés}

Ha egy tudományág „normális” úton fejlődik, akkor sok empirikus és félempirikus adatgyüjtés után jellemzően fellép valaki, aki megteremti az adott tudományág alap paradigmáját, ami hosszútávra megadja a további fejlődés tudományos kereteit ${ }^{1}$. Majd később, amikor az újabb tudás már feszegeti az eredeti paradigma határait, jön valaki más, és vagy kiegészíti az eredeti paradigmát, vagy újat alkot. A mechanika fejlődése ezt a sémát követte, hiszen „először” (óriás-elődök vállán állva) Newton megalkotta a ma már klasszikusnak nevezett mechanikát (első publikálás éve: 1687), majd több mint két évszázaddal később (1905-ben) Einstein kiterjesztette azt egy speciális esetre, a fénysebesség közelében mozgó testek esetére úgy, hogy e kiterjesztés elhanyagolhatóvá válik akkor, ha a test lassabban mozog. A tudomány fejlődése azonban nem mindig logikus - sajnos ez a helyzet a kémiai termodinamika fejlődésével is.

Szinte pontosan két évszázaddal Newton után (1875-1878-ban) Gibbs publikálta a ma már klasszikusnak számító kémiai termodinamika alapjait ${ }^{2}$, ami csak a makroszkopikus fázisokra vonatkozott. A nanotechnológia és a nano-tudományok kezdetéig elvileg volt közel 100 évünk arra, hogy azt kiterjesszük a nano-anyagokra (nano-anyagnak nevezem azokat a rendszereket, melyekben van legalább egy olyan fázis, aminek legalább az egyik kiterjedése kisebb 100 nm-nél). Itt azonban történt egy „baleset”: William Thomson (= Lord Kelvin) Gibbs művének megjelenése előtt, már 1871-ben publikált egy cikket arról, hogy a nano-méretű gömb alakú cseppekben a görbület hatására megnőtt belső nyomás következtében megnő a cseppek környezetében az egyensúlyi gőznyomás ${ }^{3}$. Tehát Kelvin az általános esetet már azelőtt kiterjesztette egy speciális esetre, hogy az általános eset megnyugtató és időtálló módon tisztázva lett volna. Ennek következtében a kémia $^{4-6}$ (és az abból kinőtt biológia ${ }^{7}$ és anyagtudomány ${ }^{8-10}$ ) ma is Kelvin-hívő, amennyiben azt a paradigmát vallja és használja, miszerint a nano-termodinamikai hatás alapvetö oka a fázis görbülete. Ez nemcsak a ma Kelvin egyenletnek nevezett egyenletre igaz (ami a nano-cseppek körüli gőznyomásra vonatkozik), hanem az abból később származtatott Gibbs-Thomson egyenletre is ${ }^{11}$ (ami a nano-kristályok olvadáspontjára vonatkozik) és az Ostwald-Freundlich egyenletre is ${ }^{12}$ (ami a nano-kristályok oldhatóságára vonatkozik). Ez utóbbi esetben érheto” történelmileg is tetten Gibbs és Kelvin megközelítéseinek ellentmondásossága: a nano-kristályok oldhatóságára ugyanis elöször Ostwald ${ }^{13}$ vezetett le egy - szerintem helyes - egyenletet, amit aztán Freundlich ${ }^{12}$ - szerintem hibásan korrigált, és paradox módon ez utóbbi van ma is használatban.

Nem is lenne semmi baj a nano-termodinamika furcsa történelmi fejlődésével, ha a Kelvin egyenlet helyes lenne. Véleményem szerint azonban nem az. Érdekes módon ezt a fizikusok régóta tudják, aminek két oka van. Egyrészt a fizika függetlenül fejlődött a kémiától, másrészt a fizikusok fö nano-objektuma nem a gömb alakú nano-csepp, hanem a görbülettel nem rendelkező vékonyréteg (film). Mivel a vékonyrétegek termodinamikai tulajdonságai (pl. olvadáspontja) vastagságfüggőek, de azok görbülettel nem rendelkeznek, így a fizikusok számára régóta nyilvánvaló, hogy a termodinamikai nano-hatás oka nem lehet a fázisok görbülete. Más kérdés, hogy ez az ellentmondás a kémikusok számára nem annyira nyilvánvaló, aminek újfent két oka van: egyrészt a kémikusok és fizikusok ritkán olvassák egymás folyóiratait, másrészt a fizikusok „elvből” nem használnak moláris mennyiségeket, emiatt nem használják se a moláris Gibbs energia, se a kémiai potenciál fogalmát ${ }^{14}$, emiatt az ellentmondás kevésbé szembetűnő.

Ebben a cikkben bemutatom a Kelvin egyenlet modern levezetését és annak tarthatatlanságát, majd bemutatom a szerintem helyes levezetést, és végül azt javasolom a magyar kémikusok közösségének, hogy a nano-termodinamikában váltsanak paradigmát. Véleményem szerint ugyanis a termodinamikai nano-hatás alapvető oka nem a fázis görbülete, hanem annak fajlagos felülete (ami definíció szerint a fázis felületének és térfogatának hányadosa). Ez a megközelítés egyrészt összhangban áll a Gibbs féle klasszikus kémiai termodinamikával, másrészt ezzel magyarázható mind a gömb alakú nano-cseppek, mind a vékonyrétegek termodinamikai viselkedése. Így a nano-anyagokkal foglalkozó kémia, anyagtudomány, biológia és fizika végre ugyanazt gondolná ugyanarról a dologról. Ez persze csak akkor fog bekövetkezni (és akkor sem biztosan), ha itt bizonyítom a ,görbület-paradigma" tarthatatlanságát és a „fajlagos felület - paradigma” helyes voltát. Ennek a cikknek ez a célja. Felhívom a figyelmet arra, hogy e cikk lényegi részét angol nyelven már publikáltam $^{15-21}$. 
A Kelvin egyenlet a nano-termodinamika egyik partikuláris problémájával foglalkozik, a nano-cseppek körüli egyensúlyi gőznyomással, ami a fáziegyensúlyok egyik példája. A fázisegyensúlyok az anyag hármas hierarchiájához (rendszer - fázis - komponens) tartozó moláris Gibbs energiáktól függenek: ezek a rendszer átlagos moláris Gibbs energiája, a fázis integrális moláris Gibbs energiája és a komponens parciális Gibbs energiája (leánykori nevén a komponens kémiai potenciálja). E három mennyiség egymással összefügg, ezért ha bármelyikről bebizonyítjuk, hogy a nano-hatás nem a görbület, hanem a fajlagos felület függvénye, azzal tézisünket bizonyítottuk. Ebben a cikkben egy egykomponensü fázis integrális moláris Gibbs energiájára koncentrálunk, mert ez a levezetés a legrövidebb. A többkomponnsü fázisokban oldott komponensek kémiai potenciáljára szóló levezetést nemrég közöltem ${ }^{21}$.

\section{A Kelvin egyenlet levezetése és tarthatatlansága}

A Kelvin egyenletet a ma szokásos, modern módon vezetem le. Ennek lényege azonos Kelvin eredeti elgondolásával, miszerint a nano-hatás a Laplace-egyenleten keresztül a fázis görbületétől függ. Kezdjük a levezetést egy egykomponensü fázis moláris Gibbs energiájának $\left(\mathrm{G}_{\mathrm{m}}, \mathrm{J} / \mathrm{mol}\right)$ közismert képletével:

$$
G_{m}=U_{m}+p \cdot V_{m}-T \cdot S_{m}
$$

ahol $\mathrm{U}_{\mathrm{m}}(\mathrm{J} / \mathrm{mol})$ a fázis moláris belső energiája, $\mathrm{V}_{\mathrm{m}}\left(\mathrm{m}^{3} / \mathrm{mol}\right)$ a fázis moláris térfogata, $\mathrm{S}_{\mathrm{m}}(\mathrm{J} / \mathrm{molK})$ a fázis moláris entrópiája, míg $\mathrm{p}$ (Pa, nyomás) és $\mathrm{T}(\mathrm{K}$, abszolút hőmérséklet) az egykomponensü rendszerek két, egymástól független állapothatározója. Most írjuk fel a Laplace egyenletet, miszerint mechanikai egyensúlyban egy görbült felületű fázis belsejében uralkodó nyomás $\left(\mathrm{p}_{\text {bent }}, \mathrm{Pa}\right)$ mindig nagyobb, mint a fázis környezetében lévő standard nyomás $\left(\mathrm{p}^{\mathrm{o}}=10^{5} \mathrm{~Pa}\right)$. Gömb alakú, $\mathrm{r}(\mathrm{m})$ sugarú fázisra a Laplace nyomás képlete ${ }^{22}$ :

$$
p_{\text {bent }}=p^{o}+\frac{2 \cdot \sigma}{r}
$$

ahol $\sigma\left(\mathrm{J} / \mathrm{m}^{2}\right)$ a fázis felületi feszültsége, míg a $2 / \mathrm{r}$ kifejezés az r sugarú gömb görbülete. Most helyettesítsük be az (1a) egyenlet $\mathrm{p}$ értéke helyére az (1b) egyenlet $p_{\text {bent }}$ értékét:

$$
G_{m}=G_{m, b}+\frac{2 \cdot \sigma}{r} \cdot V_{m}
$$

ahol a térfogati (végtelenül kis görbülettel rendelkező fázisokra):

$$
G_{m, b} \equiv U_{m}+p^{o} \cdot V_{m}-T \cdot S_{m}
$$

Az (1c) egyenlet a Kelvin-paradigma alapegyenlete: innen levezethető a Kelvin egyenlet, a Gibbs-Thomson egyenlet és az Ostwald-Freundlich egyenlet. Matematikai hiba a levezetésben nincs. Van azonban a levezetésben egy logikai ugrás: a moláris Gibbs energia képletében az egyik állapothatározót (p) azonossá tettük a Laplace egyenletből származó belső nyomással ( $\mathrm{p}_{\text {bent }}$ ), ami nyilvánvalóan nem állapothatározó. Ez az elvi oka annak, hogy a Kelvin-paradigma tarthatatlan. Ez az ok azonban túlságosan elvont ahhoz, hogy emiatt bárki paradigmát akarjon váltani. Lássunk ezért egy ennél praktikusabb okot, ami nyilvánvalóvá teszi a Kelvin paradigma tarthatatlanságát.

Elöször tegyük fel magunknak a kérdést: vajon milyen alakú egy olyan nano-csepp, amelyiket csak saját egyensúlyi gőzfázisa vesz körül (nincs a közelben más fázis), illetve a nano-csepp alakját nem zavarja meg semmilyen mező (gravitációs, stb...). Ez a kérdés szinte költői, hiszen minden kémikus tudja a helyes választ: a nano-cseppek gömb alakúak. Ilyen költői kérdéseknek csak azért van értelmük, hogy segítségükkel más, nyilvánvalónak látszó paradigmák megdönthetőek legyenek. És valóban, az (1c) egyenletből az következik, hogy egy gömb alakú nano-csepp moláris Gibbs energiája nagyobb a térfogati értéknél, hiszen mind a felületi feszültség, mind a moláris térfogat pozitív értékü mennyiségek. Ezzel szemben a görbülettel nem rendelkező fázisok (mint pl. a kocka, vagy a téglatest, vagy a vékony film) nem rendelkeznek görbülettel, ezért az (1c) egyenlet szerint moláris Gibbs energiájuk a térfogati értékkel egyenlő. E kettő összehasonlításából tehát nyilvánvaló, hogy a Kelvin-paradigmát követve arra a következtetésre jutunk, hogy a görbülettel nem rendelkező nano-cseppek moláris Gibbs energiája negatívabb a gömb alakú (görbülettel rendelkező) nano-cseppek moláris Gibbs energiájánál. Összekapcsolva ezt azzal a közismert alapelvvel, hogy az egyensúlyi fázis mindig az a fázis, amelyiknek negatívabb a moláris Gibbs energiája, innen az következik, hogy a Kelvin-paradigma szerint a nano-cseppek egyensúlyi alakja nem a gömb, hanem valamelyik, görbülettel nem rendelkezö alak, mint pl. a kocka. Mivel ez a következtetés ellentmond a fenti válasznak (miszerint a nano-cseppek a valóságban gömb alakúak), innen az következik, hogy a Kelvin-paradigma tarthatatlan. Hogy ez miért nem derült ki az elmúlt 140 évben, az azért van, mert senki nem tett fel hasonlóan költői kérdéseket, hiszen a válasz mindenkinek egyértelmü volt.

Mivel most éppen paradigma-váltásra készülünk, emlékezzünk meg a konferenciákon elhangzó leggyakoribb ellenvéleményről, miszerint a kocka alakú nano-cseppek sarkaiban igenis van görbület, ami az ott lévő atomok (molekulák) görbületével azonos. Ez igaz ugyan, de semmi köze a fázishoz - ennek csak az atomokhoz (molekulákhoz) van köze. Ráadásul, ha innen származtatnánk a nano-cseppek moláris Gibbs energiáját, akkor oda jutnánk, hogy a moláris Gibbs energia méret-független, hiszen mind a nano-kockák, mind a makro-kockák sarkaiban ugyanolyan görbületü atomok / molekulák vannak. Ez a hipotetikus eredmény azonban ellentmond a kísérleti tényeknek (miszerint a nano-cseppek tulajdonságai méretfüggőek), így ezt az ellenvetést elvethetjük. 
Egy másik ellenvetés szerint a kockákba rajzolható gömb, és annak már van görbülete (ad-abszurdum én már olyan posztert is láttam, amin egy vékonyfilmbe is gömböt rajzoltak a Kelvin-hívő szerzők). A papír sok mindent elbír, de a Laplace egyenlet lényege nem: Laplace szerint extra belső nyomás csak valódi (és nem rajzolt) görbület esetén lép fel. Ezért ezt az ellenvetést is elvethetjük.

A Kelvin paradigma tarthatatlanságának a fenti kettőn túl még több oka van: 3). ,elfeledkezik” a Gibbs féle felületi tagról, ami a fázis felületével arányos (lásd lent), ahonnan egyébként a Laplace-féle nyomás is levezethetö ${ }^{23-24}$, így azt felesleges ide visszahelyettesíteni, 4). ellentmond a Gibbs-féle csíraképződési elméletnek ${ }^{17}$. Végül, 5). pontként lássuk be, hogy a Laplace-féle belső nyomást azért is értelmetlen a moláris Gibbs energiában, vagy a kémiai potenciálban figyelembe venni, mert utóbbiak a külső hatásuk miatt érdekesek, lásd pl. a megnövelt (külső) gőznyomást a nano-cseppek körül. A Laplace nyomás kívülről nyomja befelé a görbült nano-fázist, így hozva létre egy növelt belső nyomást a külső nyomáshoz képest. A Laplace nyomás azonban nemcsak létrehozza a fázis belsejében ezt az extra nyomást, hanem rögtön kompenzálja is azt, ezért a belső megnövelt nyomás kintről érzékelhetetlen. Ha pedig ez a hatás kintről érzékelhetetlen, akkor nem is lehet semmilyen hatása arra, hogy a fázis környezetében mekkora pl. az egyensúlyi gőznyomás.

Miután (legalább magamat, talán néhány Olvasót is) több indokkal is meggyőztem a Kelvin egyenlet tarthatatlanságáról, emlékezzünk meg a Kelvin egyenlet egy kifejezetten elönyös tulajdonságáról. A Kelvin egyenlet nemcsak kétfázisú, hanem többfázisú szituációkban is értelmesnek tünő eredményeket ad. Egy ilyen eset a kapilláris kondenzáció esete, miszerint a folyadék által jól nedvesített kapillárisban lévő folyadék feletti egyensúlyi gőznyomás nem nagyobb, hanem kisebb, mint a makroszkopikus folyadék feletti egyensúlyi gőznyomás; erre az esetre az (1c) egyenlet a következőképpen módosul:

$$
G_{m, k a p}=G_{m, b}-\frac{2 \cdot \sigma}{r_{k a p}} \cdot V_{m} \cdot \cos \Theta
$$

ahol $\mathrm{G}_{\mathrm{m}, \mathrm{kap}}(\mathrm{J} / \mathrm{mol})$ a hengeres kapillárisban lévő folyadék moláris Gibbs energiája, $\mathrm{r}_{\text {kap }}(\mathrm{m})$ a hengeres kapilláris sugara, (fok) pedig a folyadék peremszöge a kapilláris belső falán, gőzközegben. Az (1e) egyenlet alapvető fontosságú, hiszen a Kelvin egyenlet kísérleti bizonyítéka is innen származik $^{25-26}$. Érdekes módon az (1e) egyenletet maguk a Kelvin-hívők is kritizálják ${ }^{6}$ : valóban, a képlet a kapillárisból kinyúló gömbsüveg görbületét tartalmazza, miközben a kapilláris falának görbülete nem $2 / \mathrm{r}_{\text {kap }}$, hanem $1 / \mathrm{r}_{\text {kap. }} \mathrm{Az}$ valóban nehezen hihetö, hogy egy végtelen hosszú kapillárisban lévő folyadék viselkedését (pl. kémiai aktivitását a kapilláris falával szemben) a felül lévő görbület és nem a fal görbülete determinálja. Ez azonban mondanivalónk szempontjából lényegtelen, hiszen mi nem korrigálni, hanem elvetni készülünk a Kelvin-paradigmát.

\section{Az új paradigma lényege}

Az új paradigma a Gibbs-féle termodinamika kiterjesztése a nano-fázisokra, amit azért kell kiterjeszteni, mert Gibbs ezt nem tette meg, azaz Gibbs nem írta fel a nano-méretü fázisokban lévő komponensek kémiai potenciáljának egyenletét, mint ahogy a fázisok moláris Gibbs energiájának egyenletét sem. Gibbs megadta azonban a felületi feszültség $\left(\sigma, \mathrm{J} / \mathrm{m}^{2}\right)$ termodinamikai definícióját:

$$
\sigma \equiv\left(\frac{d G}{d A}\right)_{p, T}
$$

ahol $\mathrm{G}(\mathrm{J})$ a fázis abszolút Gibbs energiája, $\mathrm{A}\left(\mathrm{m}^{2}\right)$ a fázist határoló felület. A (2) egyenlet leintegrálható, amennyiben két peremfeltételt használunk: az egyik szerint valamilyen véges $A$ értékhez valamilyen véges $G$ érték tartozik, míg a másik szerint ha $A=0$, akkor $G=G_{b}$, ahol $G_{b}(J)$ a fázis térfogati abszolút (nem moláris) Gibbs energiája. Az integrálás eredménye:

$$
G=G_{b}+A \cdot \sigma
$$

Ahhoz, hogy megkapjuk egy egykomponensü fázis moláris Gibbs energiáját, osszuk el a (2a) egyenletet a fázist alkotó anyagmennyiséggel (n, mol):

$$
G_{m}=G_{m, b}+\frac{A \cdot \sigma}{n}
$$

ahol $\mathrm{G}_{\mathrm{m}}(\mathrm{J} / \mathrm{mol})$ a fázis moláris Gibbs energiája $(=\mathrm{G} / \mathrm{n}), \mathrm{G}_{\mathrm{m}, \mathrm{b}}$ $(\mathrm{J} / \mathrm{mol})$ a fázis térfogati moláris Gibbs energiája $\left(=\mathrm{G}_{\mathrm{b}} / \mathrm{n}\right)$. A fázisban lévő anyagmennyiség (n) egyik lehetséges kifejezési lehetősége a térfogat $\left(\mathrm{V}, \mathrm{m}^{3}\right)$ és a moláris térfogat hányadosa $\left(\mathrm{n}=\mathrm{V} / \mathrm{V}_{\mathrm{m}}\right)$. Behelyettesítve ezt a $(2 \mathrm{~b})$ egyenletbe:

$$
G_{m}=G_{m, b}+A_{s p} \cdot V_{m} \cdot \sigma
$$

ahol $A_{\text {sp }}(1 / m)$ a fázis fajlagos felülete, azaz felületének és térfogatának hányadosa $(=\mathrm{A} / \mathrm{V})$. Mint látjuk, az $(1 \mathrm{c})$ és a (2c) egyenletek nagyon hasonlítanak egymásra. Az egyetlen eltérés az, hogy míg a Kelvin-paradigma szerint a nano-hatást a nagy görbület okozza, addig a (2c) egyenlet szerint ugyanezt a nagy fajlagos felület okozza. Görbült fázisok esetén az (1c, 2c) egyenletek hasonlóak, bár nem azonosak. Egy r sugarú gömbre például a görbület 2/r, míg a fajlagos felület 3/r. Egy $\mathrm{r}_{\mathrm{kap}}$ sugarú kapilláris palástjára a görbület $1 / r_{\text {kap }}$, míg a fajlagos felület $2 / r_{\text {kap }}$. Kelvin idejében ezek a mennyiségi különbségek a koefficiensekben még lényegtelenek voltak. Ma azonban, a méréstechnika fejlődésével és a nano-tudomány térnyerésével már egyre kevésbé mindegy, hogy a nano-hatás képletében 2-es, vagy 3 -as (1-es, vagy 2 -es) numerikus koefficiens van.

A mennyiségi különbség az (1c, 2c) egyenletek között a nem görbült felületü fázisok esetére minőségi különbséggé válik. Hiszen görbületük ugyan e fázisoknak valóban nincs, de nagy fajlagos felületük van. Közismert, hogy a 3-dimenziós, azonos térfogatú geometriai testek közül a gömb fajlagos 
felülete a legkisebb (a kockával, a téglatesttel, a vékony filmmel, stb. való összehasonlításban). Ily módon az összes három-dimenziós alak közül a gömb alakú fázisoknak a legkisebb a moláris Gibbs energiájuk, ahonnan már érthető, hogy miért gömb (és miért nem kocka) alakúak a nano-cseppek. Emlékeztetek, hogy ezen a primitív teszten a Kelvin-egyenlet megbukott, hiszen abból a kocka alakú csepp stabilabbnak tünt a gömb alakú cseppnél (lásd fent).

Érdemes megjegyezni, hogy a (2c) egyenlethez hasonló képlet vezethető le (bár bonyolultabban) a többkomponensű fázisok moláris Gibbs energiájára és az ilyen fázisokban oldott komponensek kémiai potenciáljára is ${ }^{21}$. Ugyanitt $^{21}$ adtam meg azt az általános képletet, amivel egy kétfázisú szituációban lévő nano-fázis (amikor a nano-fázis csak az őt körülvevő egyensúlyi gőzfázissal tart egyensúlyt) moláris Gibbs energiája átszámítható ugyanezen nano-fázis moláris Gibbs energiájává bármely többfázisú szituációban $\left(\mathrm{G}_{\mathrm{m}, \mathrm{sok}}, \mathrm{J} / \mathrm{mol}\right)$ :

$$
G_{m, s o k}=G_{m, b}+A_{s p} \cdot V_{m} \cdot \sigma+\frac{V_{m}}{V} \cdot\left(G_{s o k}-G_{1}\right)
$$

ahol $\mathrm{G}_{\mathrm{sok}}(\mathrm{J})$ a sok fázissal kontaktusban lévő nano-fázist tartalmazó rendszer abszolút (nem moláris) Gibbs energiája, míg $\mathrm{G}_{1}(\mathrm{~J})$ a csak egy fázissal (az egyensúlyi gőzfázissal) kontaktusban lévő (de az összes többi fázist is tartalmazó) nano-fázist tartalmazó rendszer abszolút (nem moláris) Gibbs energiája. Alkalmazva a (2d) egyenletet a hengeresen kapillárisban lévő folyadékra, végeredményként az (1e) egyenletet kapjuk $^{21}$. Ez az új paradigma szempontjából megnyugtató, hiszen ennek az egyenletnek kísérleti bizonyítéka van ${ }^{25-26}$. Ugyanakkor ez egy meglepő fordulat, hiszen ezzel úgy tünik, mintha visszatértünk volna a Kelvin-paradigmához. Valójában ez csak a látszat, hiszen a Kelvin-paradigmán belüli hibás levezetésben a $2 / \mathrm{r}_{\text {kap }}$ a gömb (és nem a hengerpalást) görbülete, míg a mi levezetésünkben $2 / r_{\text {kap }}$ a hengerpalást fajlagos felülete.

Most bemutatom a (2d) egyenlet müködését arra az esetre, amikor egy nano-csepp két, egymástól d távolságra lévő, párhuzamos szilárd fal között helyezkedik el, mely négyzet keresztmetszetủ és L élhosszúságú, és a folyadék teljesen kitölti ezt a négyzet alapú, téglatest rést. A téglatest térfogata és folyadékkal érintkező felülete:

$$
\begin{aligned}
& V=d \cdot L^{2} \\
& A=2 \cdot L^{2}
\end{aligned}
$$

A (3a-3b) egyenletek hányadosából a fajlagos felület: $A_{\text {sp }}=2 /$ d. Először írjuk fel a (2d) egyenletben szereplő $G_{1}$ Gibbs energia értékét arra az esetre, amikor a rendszer egy d*L*L méretü, különálló nanocseppből és az ugyanilyen méretü, de üres (gőzt tartalmazó) résből áll:

$$
G_{1}=\sum n \cdot G_{m, b}+A \cdot\left(\sigma_{s g}+\sigma_{l g}\right)
$$

ahol az első tag a három fázis (szilárd, folyadék gőz) anyagmennyiségeinek és moláris térfogati Gibbs energiáinak szorzata, míg a második tag a felületi tag, összhangban Gibbs (2a) képletével, ahol $\sigma_{\mathrm{sg}}\left(\mathrm{J} / \mathrm{m}^{2}\right)$ a szilárd felületi energiája, $\sigma_{\mathrm{lg}}$ $\left(\mathrm{J} / \mathrm{m}^{2}\right)$ a folyadék felületi feszültsége. A (3c) egyenletben elhanyagoltuk az egyéb felületeket, mivel feltételezzük, hogy $\mathrm{L}>>$ d. Most írjuk fel a (2d) egyenlet szerinti $\mathrm{G}_{\text {sok }}$ képletét arra az esetre, amikor a folyadék fázis a két szilárd közötti résben helyezkedik el:

$$
G_{s o k}=\sum n \cdot G_{m, b}+A \cdot \sigma_{s l}
$$

ahol $\left(\mathrm{J} / \mathrm{m}^{2}\right)$ a szilárd/folyadék határfelületi energia. Most helyettesítsük be a (3a-d) egyenleteket (és az innen következő $\mathrm{A}_{\mathrm{sp}}=2 /$ d kifejezést) a (2d) egyenletbe. A Young egyenlet figyelembe vételével $\left(\sigma_{\mathrm{lg}} \cdot \cos \Theta=\sigma_{\mathrm{sg}}-\sigma_{\mathrm{sl}}\right)$ és egyszerüsítések után a következő egyenlethez jutunk:

$$
G_{m, r e ́ s}=G_{m, b}-\frac{2}{d} \cdot V_{m} \cdot \sigma \cdot \cos \Theta
$$

ahol $\mathrm{G}_{\mathrm{m} \text {,rés }}(\mathrm{J} / \mathrm{mol})$ a d vastagságú résben lévő folyékony fázis moláris Gibbs energiája. Összehasonlítva a (3e, 1e) egyenletek, a hasonlóság nyilvánvaló, a különbség csak a két esetre vonatkozó fajlagos felület kifejezésében van. A (3e) egyenletből az következik, hogy 1). a nano-résben elhelyezkedő folyékony fázisnak azonos a Gibbs energiája a makroszkopikus cseppel, ha a nedvesítés semleges $\left.\left(\Theta=90^{\circ}\right), 2\right)$. a nano-résben elhelyezkedő folyékony fázis stabilabb állapotban van, mint a makroszkopikus csepp, ha a csepp jól nedvesíti a szilárd fázist $\left(\Theta<90^{\circ}\right)$ és 3). a nano-résben elhelyezkedő folyékony fázis instabilabb állapotban van, mint a makroszkopikus csepp, ha a csepp rosszul nedvesíti a szilárd fázist $\left(\Theta>90^{\circ}\right)$; ez annyira igaz, hogy emiatt az ilyen folyadék ki is „menekül” a nem nedvesített falú résből. Ebböl az a közismert tény következik, hogy a nano-fázisok moláris Gibbs energiája nemcsak az adott fázis saját (térfogati) tulajdonságaitól függ, hanem attól is, hogy milyen fázisokkal és milyen konfigurációban van kontaktusban.

\section{Következtetések}

Öt különböző módon indokoltuk, hogy a Kelvin paradigma miért tarthatatlan a nano-termodinamika leírására. A Gibbs féle termodinamika kiterjesztésével levezettünk egy új általános egyenletet, ami nem a fázis görbületéhez, hanem annak fajlagos felületéhez köti a nano-fázisok moláris Gibbs energiáját. Ezt kiterjesztettük a több fázissal kontaktusban lévő nano-fázisok esetére is. Ezzel az új paradigma készen áll arra, hogy lecserélje az eddig jó szolgálatot tett, de több okból hibásnak talált Kelvin-paradigmát. Most már „,csak” a tudományos közösségen múlik, hogy ez a cikk észrevétlen marad, vagy az itt javasolt paradigma-váltás valóban bekövetkezik.

\section{Köszönetnyilvánítás}

A cikkben ismertetett eredmények a GINOP-2.3.2-152016-00027 jelü „Kristályos és amorf nanoszerkezetü anyagok kutatásával és fejlesztésével foglalkozó kiválósági műhely fenntartható müködtetése" címü projekt részeként keletkezett, ami a Széchenyi 2020 keretében az Európai Unió támogatásával valósul meg. 


\section{Hivatkozások}

1. Kuhn, T.S. The structure of scientific revolutions. The University of Chicago Press, 1962. ISBN: 0-226-45808-3

2. Gibbs, J.W. On the Equilibrium of Heterogeneous Substances. Trans. Conn. Acad. Arts Sci. 1875, 3, 108-248 and 1878, 3, 343-524

3. Thomson, W. On the equilibrium of vapour at a curved surface of liquid. Phil. Mag. 1871;42, 448-452. https://doi.org/10.1080/14786447108640606

4. Adamson, A.W. Physical Chemistry of Surfaces, 5th ed., John Wiley and Sons Inc., NY, 1990.

ISBN: 0-471-61019-4

5. Atkins, P.; de Paula, J. Physical Chemistry, 7th ed. Oxford Oxford University Press, 2002. ISBN: 0-19-879285-9

6. Butt, H.N.; Graf, K.; Kappl, M. Physics and Chemistry of Interfaces. Weinheim: Wiley; 2003.

ISBN: 978-3-527-60640-5

https://doi.org/10.1002/3527602313

7. Wais, U.; Jackson, A.W.; He, T.; Zhang, H. Nanoformulation and encapsulation approaches for poorly water-soluble drug nanoparticles. Nanoscale. 2016, 8, 1746-1769. https://doi.org/10.1039/C5NR07161E

8. Kurz, W.; Fisher, D.J. Fundamentals of Solidification, 3rd ed. Lausanne: Trans Tech Publ;1989. ISBN: 0878495223

9. Eustathopoulos, N.; Nicholas, M.G.; Drevet, B. Wettability at High Temperatures. New York: Pergamon; 1999. ISBN: 9780080421469

10. Hornyak, G.L.; Dutta, J.; Tibbals, H.F.; Rao, A.K. Introduction to Nanoscience. New York: CRC Press; 2008 ISBN: 9781420047790 https://doi.org/10.1201/9781420047806

11. Thomson, J.J.; Application of dynamics to physics and chemistry. MacMillan, London, 1888.

12. Freundlich, H. Kolloidchemie. Akademischer Verlag, Leipzig 1909 (English translation: 1923, E.P. Dutton Co Publ., New York).

13. Ostwald, W. Über die vermeintliche Isomerie des roten und gelben Quescksilberoxyds und die Oberflachenspannung fester Körper. Z. Phys. Chem. 1900, 34, 495-503.

14. Beke D.L.; Cserháti C.; Szabó I.A. Segregation inhibited grain coarsening in nanocrystalline alloys. J. Appl. Phys. 2004, 95, 4996-5001. https://doi.org/10.1063/1.1688461

15. Kaptay, G. Nano-Calphad: extension of the Calphad method to systems with nano-phases and complexions. J. Mater. Sci. 2012, 47, 8320-8335.

https://doi.org/10.1007/s10853-012-6772-9
16. Kaptay, G. On the size and shape dependence of the solubility of nano-particles in solutions. Int J. Pharma. 2012, 430, 253-257.

https://doi.org/10.1016/j.ijpharm.2012.03.038

17. Kaptay, G. The Gibbs equation versus the Kelvin and the Gibbs-Thomson equations to describe nucleation and equilibrium of nano-materials. J. Nanosci. Nanotechnol. 2012, 12, 2625-2633.

https://doi.org/10.1166/jnn.2012.5774

18. Kaptay, G.; Janczak-Rusch, J.; Pigozzi, G.; Jeurgens, L.P.H. Theoretical analysis of melting point depression of pure metals in different initial configurations. J. Mater. Eng. Perform. 2014, 23, 1600-1607. https://doi.org/10.1007/s11665-014-0885-z

19. Yakymovych, A.; Kaptay, G.; Roshanghias, A.; Falndorfer, H.; Ipser, H. Enthalpy effect of adding cobalt to liquid Sn-3.8Ag-0.7Cu lead-free solder alloy: difference between bulk and nanosized cobalt. J. Phys. Chem. C, 2016, 120, 1881-1890. https://doi.org/10.1021/acs.jpcc.5b09445

20. Kaptay, G.; Janczak-Rusch, J.; Jeurgens, L.P.H. Melting Point Depression and Fast Diffusion in Nanostructured Brazing Fillers Confined Between Barrier Nanolayers. $J$. Mater. Eng. Perform., 2016, 25, 3275-3284. https://doi.org/10.1007/s11665-016-2123-3

21. Kaptay, G. A new paradigm on the chemical potentials of components in multi-component nano-phases within multi-phase systems. $R S C A d v, 2017,7,41241-41253$. https://doi.org/10.1039/C7RA07911G

22. de Laplace PS. Mechanique Celeste, Supplement to Book 10. 1806.

23. Kaptay, G. Classification and general derivation of interfacial forces, acting on phases, situated in the bulk, or at the interface of other phases. J. Mater. Sci. 2005, 40, 2125-2131. https://doi.org/10.1007/s10853-005-1902-2

24. Kaptay, G. Interfacial Forces in Dispersion Science and Technology. J. Disper. Sci. Technol. 2012, 33, 130-140. https://doi.org/10.1080/01932691.2010.548232

25. Fisher, L.R.; Israelachvili, J.N. Experimental studies on the applicability of the Kelvin equation to highly curved concave menisci. J. Colloid Interf. Sci. 1981, 80, 528-541. https://doi.org/10.1016/0021-9797(81)90212-5

26. Christenson, H.K. Capillary condensation in systems of immiscible liquids. J. Coll. Interface Sci. 1985, 104, 234-249. https://doi.org/10.1016/0021-9797(85)90028-1

\section{Kelvin's curvature vs. Gibbs' surface area: the two contradicting paradigms of nano-thermodynamics}

The paper describes the Kelvin paradigm of nanothermodynamics and shows why it is inadequate (= wrong). To replace it, the author extends the thermodynamics of Gibbs and shows that the nano-effect is in fact due to the high specific surface area of a phase and not to its high curvature. The new equation is extended to cases when the nano-phase is in multi-phase situations. Particularly a nano-liquid is considered, being confined in the nano-slit between two, parallel solid plates. It is shown that the molar Gibbs energy of the nano-phase depends on its configuration and the type and morphology of other phases in contact with the nano-phase. It is finally concluded that the Kelvin paradigm should be replaced by the new paradigm offered here and in the paper previously published by the author in RSC Adv, 7 (2017) 41241-41253 (doi: 10.1039/c7ra07911g).

When such an important paradigm like the Kelvin paradigm of nano-thermodynamics is criticized, it must be well supported even if it is done in a short English abstract.

First, when the basic Kelvin equation (1c) is derived, the state parameter ( $p$, pressure) is replaced by the inner pressure within a curved phase. However, this latter pressure is not a state parameter, so this step in the derivation of the Kelvin equation is principally wrong. 
The author realizes, however, that few paradigms are replaced for principal problems. That is why a practical contradiction is also provided here. First the question is asked about the equilibrium shape of an independent, liquid nano-droplet, being far from other phases (except the equilibrium vapor phase) and being not under the influence of any field such as gravity. Under these constraints "it is known" that nano-droplets are spherical. Now, let us see the answer of the Kelvin equation for this simple question. As follows from Eq.(1c), the Kelvin equation predicts a higher molar Gibbs energy for spherical nano-droplets compared to the spherical macro-droplets (this is because small spheres have large curvatures). On the other hand, the same Kelvin equation predicts identical molar Gibbs energy for cubic nano-droplets, cubic macro-droplets and spherical macro-droplets (this is because cubes have no curvature and macro-spheres have negligible curvature). Thus, it follows that when a spherical nano-droplet is compared to the cubic nano-droplet of the same volume, the latter has a more negative molar Gibbs energy, and thus nano-droplets should be cubic, at least, as predicted by the Kelvin equation. As this conclusion contradicts experimental observations (nanodroplets are not cubic, rather spherical), it follows that the Kelvin equation must be inadequate.

Now, let us copy here the most frequently raised comment about the above logic. It is frequently claimed that cubes also have their own curvature, perpendicular to their corners, and so the Kelvin equation is applicable. Indeed, cubes have corners and the atoms / molecules sitting in the corners of the cubes have their own curvatures. However, this is not the curvature of the phase this is rather the curvature of the atom / molecule in the corner of a cubic phase. Moreover, this curvature is the same for small and large cubic phases, and thus it follows that the nano-effect seems to be size-independent. However, the latter also contradicts experimental facts, so this frequently raised comment is rejected.

Another comment is that spheres can be inscribed into cubes, and in this way cubes become curved. Indeed, I have even seen a poster with a sphere inscribed into a thin film. These are considered useful tricks to overcome the problem that something is wrong with the Kelvin equation. However, one should do such tricks within the framework of the Kelvin paradigm. When the moment comes to replace the Kelvin paradigm, such tricks do not help anymore.

Another reason why the Kelvin equation is inadequate because it "forgot" about the surface term of Gibbs (= the surface area multiplied by the surface tension). In fact, Kelvin himself in 1871 did not forget about this term, as this term was introduced only in 1878 by Gibbs. This term has been forgotten only by the followers of Kelvin since 1878 .

Another reason why the Kelvin equation is inadequate because it contradicts the nucleation theory of Gibbs, also introduced in 1878. According to the Kelvin equation the equilibrium size of the phase is identical to the critical nucleus size of the same phase, corresponding to the maximum and not to the minimum of the Gibbs energy, while the minimum of the Gibbs energy (and not its maximum) corresponds to the equilibrium state (for more details see reference 17 above).

Finally, as we know after Lewis, who called "activity" first as "escaping tendency", the increased activity (or increased chemical potential, or increased partial Gibbs energy) of a component in a phase acts outside of the phase, leading to increased vapor pressure, or increased chemical reactivity of the given component. Now, let us note that the Laplace pressure is not sensible outside of the curved phase. The increased inner pressure due to high curvature of a phase is induced by the curvature, but it is also compensated by the same curvature, that is how the inner part of this phase keeps equilibrium with a surrounding phase of lower pressure. Thus, the increased inner pressure, not sensible outside the phase cannot lead to the increased vapor pressure or to the increased chemical reactivity of the component outside the curved phase. Thus, the essence of the Kelvin paradigm, claiming that the increased curvature of a nano-phase is the basic reason for increased activity, vapor pressure or reactivity of components of this phase, is inadequate (= wrong, if simple English is used).

The Kelvin paradigm will be put into a museum of science of chemistry (similarly as it is already put into the museum of science of physics), if another, better paradigm is offered instead. The new paradigm should provide reasonable answers to all questions successfully answered by the Kelvin paradigm and beyond: it also should provide contradiction-free answers to questions, for which the Kelvin equation fails to do so. In this paper and in some previous papers of the author (see references 15-21 of the reference list) the new paradigm is derived from the work of Gibbs. Although Gibbs did not offer a clear answer to the questions of nano-thermodynamics, the teachings of Gibbs can be developed further to gain the required answers. After Gibbs, the nano-effect is due to the increased specific surface area of a nano-phase. This is discussed in this paper and other papers mentioned above.

The absolute Gibbs energy of a phase can be written as the sum of its bulk Gibbs energy and its surface Gibbs energy, the latter defined by Gibbs as the product of surface area and surface tension (this term is essentially the work done to create a surface). The molar Gibbs energy of the same phase follows as the absolute Gibbs energy divided by the amount of matter within the phase. Then, the surface term becomes the product of the specific surface area times the molar volume times the surface tension, when the specific surface area is defined as the ratio of the surface area to the volume of the phase. This is the essence of the new paradigm of nano-thermodynamics. This should be extended to nano-phases in multi-phase situations, which is shown here for the case of the liquid confined into nano-slits between parallel solid phases. 